\title{
Treatment of Gingival Inflammation with Turmeric Extract Gel
}

\author{
Zaki Mubarak ${ }^{1, *}$, Sunnati Sunnati ${ }^{2}$, Sri Rezeki ${ }^{3}$ \\ ${ }^{1}$ Department of Oral Biology, Dentistry Faculty, Universitas Syiah Kuala. Jl. Teuku Nyak Arief No.441, \\ Kopelma Darussalam, Kec. Syiah Kuala, Kota Banda Aceh, Aceh 23111. Indonesia. \\ E-mail: zakimubarak@unsyiah.ac.id \\ ${ }^{2}$ Department of Periodontology, Dentistry Faculty, Universitas Syiah. Kuala. Jl. Teuku Nyak Arief No.441, \\ Kopelma Darussalam, Kec. Syiah Kuala, Kota Banda Aceh, Aceh 23111. Indonesia. \\ E-mail: sunnatidrg99@unsyiah.ac.id \\ ${ }^{3}$ Department of Oral Medicine, Dentistry Faculty, Universitas Syiah. Kuala. Jl. Teuku Nyak Arief No.441, \\ Kopelma Darussalam, Kec. Syiah Kuala, Kota Banda Aceh, Aceh 23111. Indonesia. \\ E-mail: iy 99fkg@unsyiah.ac.id
}

*Corresponding author. E-mail:zzakimubarak@unsyiah.ac.id

\begin{abstract}
Gingivitis is inflammation of the gingival tissue without loss of attachment and destruction of the alveolar bone. Many natural ingredients are currently used to treat gingivitis, one of which is turmeric. This study is a laboratory experimental study that aims to determine the effectiveness of turmeric in the form of a gel with a concentration of $12.5 \%$ in reducing the gingival index. Wistar rats (Rattus Copernicus) were used as experimental animals for manipulation of gingivitis using wire ligature. The gingivitis was then applied with turmeric extract gel with a concentration of $12.5 \%$. The results of statistical tests using the Kruskal Wallis Test showed $\mathrm{p}=0.03(\mathrm{p}<0.05)$, which indicated a significant difference between the study groups. This study concluded that $12.5 \%$ turmeric extract gel was effective in reducing the gingival index in gingivitis-induced rats.
\end{abstract}

Keywords: gingivitis, turmeric extract gel, curcumin, gingival index.

\section{INTRODUCTION}

Gingivitis is inflammation confined to the gingival tissue and clinically does not show any loss of attachment [1]. Subgingival plaque is a potential site for bacteria to multiply $[2,3,4]$. This disease is the second most common oral cavity disease in the community [5,6]. The main cause of gingivitis is the accumulation of microbial plaque on the cervical and surrounding teeth. Gingivitis is an infectious disease that has clinical symptoms such as redness, swelling, loss of free gingival texture, and bleeding on probing $[7,8,9]$.

The utilization of natural resources as alternative medicine is currently growing rapidly. Medicinal plants can be used as alternative medicines because they are easy to obtain and have relatively few side effects. One of the natural plants that have long been known as medicinal plants is turmeric [10]. Turmeric has pharmacological effects such as blood circulation and vital energy, eliminating blockages in menstrual laxatives, anti-inflammatory, facilitating childbirth, antibacterial, facilitating bile secretion (cholagogues), carminative and astringent [11].
Curcumin contained in turmeric also functions as an anti-inflammatory [12].

\section{MATERIALS AND METHODS}

The turmeric rhizome extraction process was carried out by the maceration method using ethanol as a solvent. A total of $120 \mathrm{~g}$ of turmeric rhizome extract were soaked in $750 \mathrm{~mL}$ of $96 \%$ ethanol solution. After 5 days, the soaked sample was filtered using filter paper to produce filtrate 1 and dregs 1 . The dregs were then macerated with $75 \mathrm{~mL}$ of $96 \%$ ethanol solution, covered with aluminum foil, and left for 2 days while stirring occasionally. After 2 days, the sample was filtered using filter paper or flannel to produce filtrate 2 and dregs 2 . The filtrate 1 and 2 were combined, then evaporated using a rotary evaporator at a temperature of $40^{\circ} \mathrm{C}-50^{\circ} \mathrm{C}$, so that a thick turmeric rhizome extract was obtained. The resulting viscous extract was left at room temperature until all of the ethanol solvents had evaporated. The extracts were weighed and stored in a sealed glass container before being used for testing.

The process of making turmeric rhizome extract gel preparation began with weighing all the required ingredients according to the calculation. The 
next step was to develop a gelling agent, then add additional ingredients (such as preservatives, penetration enhancers, etc.) into the gelling agent which was already in finished form. Furthermore, the active substance of turmeric rhizome ethanol extract was added to the gel preparation. Gel preparations were made with a concentration of $12.5 \%$.

This study used 9 male white rats aged \pm 2 months. White rats were placed in a room with husks on the floor for 2 weeks. The room was regulated with lighting cycles by providing a dark and light cycle of 12 hours at a temperature of 23-250C. The white rats were given the same standard feed and drink ad libitum. Then the rats were anesthetized by intramuscular injection with a combination of $0.1 \mathrm{Ml}$ of ketamine hydrochloride and $0.05 \mathrm{~mL}$ of xylazine hydrochloride $(2 \mathrm{~g} / 100 \mathrm{~mL})$ of every $100 \mathrm{~g}$ of body weight. After anesthesia, a sterile 4/0 suture was placed around the right submarginal lower incisor for 4 days.

The rat's gingival condition was assessed using the Gingival Index (GI). The score of each tooth was obtained by adding up the scores of the four sides examined, then divided by four (the number of sides examined). A value of 0 indicates healthy gingiva, a value of 1 indicates there is mild gingival inflammation, the gingiva is characterized by discoloration, slight edema, on palpation there is no bleeding. A value of 2 indicates moderate gingival inflammation, red, edematous, and shiny gingiva, bleeding on palpation. A score of 3 indicates severe gingival inflammation, marked red gingiva, edema, ulceration, gingival tendency to bleed spontaneously. Gingival Index (GI) is the severity of gingival inflammation clinically can be determined from the Gingival Index score with the following criteria: gingival index score $0.1-1.0$ mild gingivitis, gingival index score $1.1-2.0$ moderate gingivitis, gingival index score $2.1-3.0$ severe gingivitis. The turmeric extract gel was given once a day, for one week.

\section{RESULTS}

With the maceration method, turmeric extract was obtained as shown in Figure 1 below.

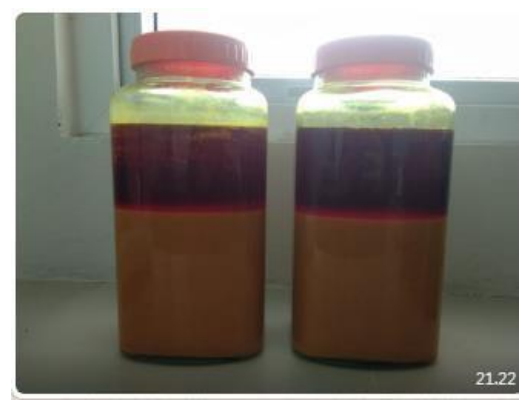

Figure 1. Extract turmeric rhizome using ethanol solvent.

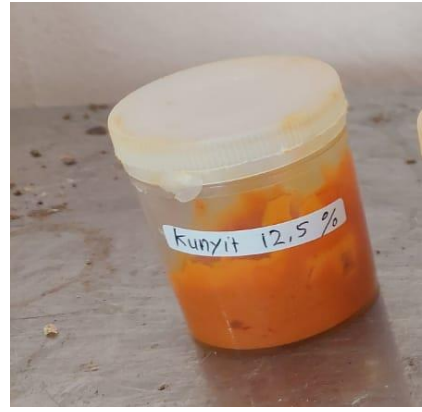

Figure 2. Preparation of Turmeric Extract Gel with a Concentration of $12.5 \%$.

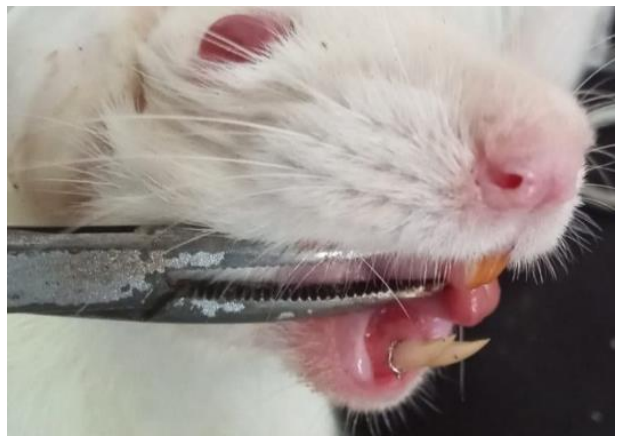

Figure 3. Gingivitis induction with wire ligature.

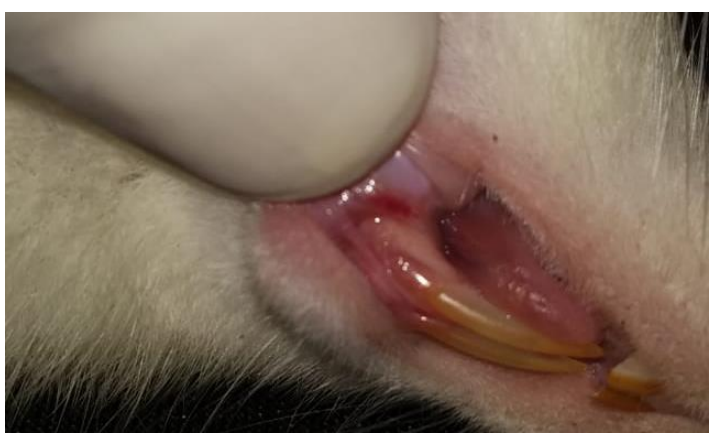

Figure 4. The gingiva condition after the induction of gingivitis.

Table 1. Gingival index after induction of gingivitis

\begin{tabular}{|c|c|c|c|}
\hline \multicolumn{4}{|c|}{ Gingival Index (GI) } \\
\hline Rat & Group 1 & Group 2 & Group 3 \\
\hline 1 & 2 & 2 & 3 \\
\hline 2 & 2 & 2 & 3 \\
\hline 3 & 3 & 3 & 3 \\
\hline 4 & 2 & 2 & 2 \\
\hline 5 & 3 & 2 & 2 \\
\hline
\end{tabular}

Group $1=12.5 \%$ Turmeric Extract Gel Group

Group 2 = Positive Control Group (Metronidazole Gel)

Group 3 = Negative Control Group (Aquades Gel) 
Table 2. The Gingival index after application of $12.5 \%$ turmeric extract gel

\begin{tabular}{|c|c|c|c|}
\hline \multicolumn{5}{|c|}{ Day 7 } \\
\hline Rat & Group 1 & Group 2 & Group 3 \\
\hline 1 & 0 & 0 & 1 \\
\hline 2 & 0 & 0 & 2 \\
\hline 3 & 0 & 0 & 3 \\
\hline 4 & 0 & 0 & 2 \\
\hline 5 & 1 & 0 & 1 \\
\hline
\end{tabular}

Group 1 = Turmeric Extract Gel Group

Group 2 = Positive Control Group (Metronidazole Gel)

Group 3 = Negative Control Group (Aquades Gel)
Table 3. Tests of Normality

\begin{tabular}{|l|l|l|l|l|l|l|}
\hline & \multicolumn{3}{|l|}{ Kolmogorov- } & \multicolumn{3}{l|}{ Shapiro-Wilk } \\
Smirnov
\end{tabular}

a. Lilliefors Significance Correction

The results of the normality test of the data above showed that the data is not normally distributed $\mathrm{p}=0.001(\mathrm{p}<0.05)$. The results of statistical tests using the Kruskal Wallis Test showed $\mathrm{p}=0.03 \quad(\mathrm{p}<0.05)$, which indicated a significant difference between the study groups.

Table 4. Post hoc test results

Each node shows the sample average rank of Kelompok.

\begin{tabular}{|lrrrrr|}
\hline Sample1-Sample2 & $\begin{array}{c}\text { Test } \\
\text { Statistic }\end{array}$ & $\begin{array}{c}\text { Std. } \\
\text { Error }\end{array}$ & $\begin{array}{l}\text { Std. Test } \\
\text { Statistic }\end{array}$ & Sig. & Adj.Sig. \\
\cline { 2 - 7 } Kelompok 2-Kelompok 1 & 1,200 & 2,493 &, 481 &, 630 & 1,000 \\
\hline Kelompok 2-Kelompok 3 & $-7,800$ & 2,493 & $-3,129$ &, 002 &, 005 \\
\hline Kelompok 1-Kelompok 3 & $-6,600$ & 2,493 & $-2,648$ &, 008 &, 024 \\
\hline
\end{tabular}

Each row tests the null hypothesis that the Sample 1 and Sample 2 distributions are the same.

Asymptotic significances (2-sided tests) are displayed. The significance level is ,05.

Note:

o Group 1 = Turmeric Extract Gel Group

o Group 2 = Positive Control Group (Metronidazole Gel)

o Group 3 = Negative Control Group (Aquades Gel)

Post Hoc test (Dunn Boferonni) showed that there was a significant difference between the positive control group and the negative control group ( $\mathrm{p}=0.05)$, as well as the extract group and the negative control group $(\mathrm{p}=0.024)$. However, there was no significant difference between the extract and positive control groups $(\mathrm{p}=1.00)$.

\section{DISCUSSION}

In this study, the white rats used were male rats because female white rats have an estrus phase which can cause hormonal imbalances [13], so the effect of the turmeric extract gel that will be given cannot work optimally and this can bias the results of this study. This is also based on research that observes gingivitis as an inflammation of which one of the predisposing factors is hormonal conditions [14].

Gingivitis manipulation in ten rats was performed using a wire ligature placed on the submarginal of the rat's gingiva. This method was chosen because it had various advantages such as easy operation, faster inflammatory effect, and less cost than the gingivitis induction method using bacterial inoculation. Gingivitis was caused by the use of wires at the gingival submarginal due to the accumulation of plaque in the area where the wires were attached [15].

This study showed that there was a decrease in GI after administration of $12.5 \%$ turmeric extract gel when compared to the negative control group. These results are consistent with the study of Chatterjee et al who found that curcumin is effective against gingivitis, the study of Chatterjee et al used curcumin in the form of a mouthwash [16]. The results of Farjana et al's study also found that oral Curcuma gel containing $10 \mathrm{mg}$ of Curcuma longa was effective in treating gingivitis and reducing the inflammatory component [17]. In this study, it was also found that 
the ability of curcumin in the form of $12.5 \%$ gel had the same ability as the positive control, namely metronidazole gel. This showed that turmeric extract gel is effective in decreasing the gingival index and can be used as alternative medicine in the treatment of gingivitis.

\section{CONCLUSION}

Turmeric extract gel of $12.5 \%$ was effective in decreasing the gingival index in gingivitis-induced rats.

\section{CONFLICT OF INTEREST}

The authors declare no conflict of interest.

\section{ACKNOWLEDGMENTS}

This research was funded by LPPM Universitas Syiah Kuala through Professor Research Grant Number: 166/UN11/SPK/PNBP/2021 dated 19 February 2021. Thanks to the Laboratory of Microbiology and Research of Faculty of Veterinary Medicine, Universitas Syiah Kuala, Darussalam Banda Aceh, Indonesia.

\section{REFERENCES}

[1] J.E. Hinrichs, M.J. Novak. Classification of disease conditioning affecting the periodontium. In: M.G Newman, H.H Takei, P.R. Klokkevold, F.A. Carranza, eds Carranza's Clinical Periodontology 11th ed. ST Louis: Saunder Elsevier; 2012. pp. 34-40.

[2] N.Samuels, T.G. John, J.S. Aron, D.W. Isaiah, C.W. Ray. Effect of an herbal mouth rinse in preventing periodontal inflammation in an experimental gingivitis model: a pilot study. Compendium 2012; 33(3), pp. 204-211.

[3] B.L. Pihlstrom, B.S. Michalowicz, N.W. Johnson. Periodontal disease. Lancet 2005; 366 (9499), pp. 1809-1820.

[4] I.P. Dermawan, W.Yanuaris, P. Indra. Pengaruh kumur-kumur larutan hexetidine $0,1 \%$ terhadap penurunan akumulasi plak. FKG Unmas Denpasar 2004, pp.1-4.

[5] T.K. Ababneh, M.Z. Faisal, S.Y. Khader. Prevalence and risk indicators of gingivitis and periodontitis in a multi-centre study in North Jordan: a cross sectional study. BMC Oral Health 2012; 12(1), pp. 1-8.
[6] M.A.B. Rebelo, M.C. Lopes, J.M.R. Vieira, R.C.P. Parante. Dental caries and gingivitis among 15 to 19 year-old students in Manaus, AM, Brazil. Braz. Oral Res 2009; 23(3), pp.245-254.

[7] M.E. Rateitschak, H. Klaus, T.M. Hassell. Disease of the periodontium. In:Color Atlas of Periodontology.New York. 1985.pp.33.

[8] J.P. Fiorellini, D.M. Kim, N.G. Uzel. Gingival inflammation. In: Carranza's Clinical Periodontology (In: M.G Newman, H.H Takei, P.R. Klokkevold, F.A. Carranza,), ed,11. St. Louis, Missouri: Elsevier Saunders, 2012. pp. 72-75.

[9] J.P. Fiorellini, D.M. Kim, N.G. Uzel. Clinical features of gingivitis. In: Carranza's Clinical Periodontology (In: M.G Newman, H.H Takei, P.R. Klokkevold, F.A. Carranza,), ed,11. St. Louis, Missouri: Elsevier Saunders, 2012. pp. 7683.

[10] Y. Mulyani, G. Wulandari, A. Sulaeman. Review: Peran Kunyit (Curcuma longa) Sebagai terapi Hipertensi dan Mekanismenya Terhadap Ekspresi Gen. MFF 2021; 25(2), pp. 51-58.

[11] Said, Ahmad, 2001. Khasiat \& Manfaat Kunyit. PT. Sinar Wadja Lestari.

[12] N. Chainani-Wu. Safety and anti-inflammatory activity of curcumin: a component of tumeric (Curcuma longa). J Altern Complement Med. 2003; 9(1), pp. 161-68.

[13] D. Kusumawati. Bersahabat dengan hewan coba. Fakultas Kedokteran Hewan Universitas Airlangga. 2004. pp. 8-10.

[14] S.H. Dalimunthe. Periodonsia. Edisi revisi. Medan: Fakultas Kedokteran Gigi Universitas Sumatera Utara, 2008. pp. 9-19, 78-83, 99-100, 154157.

[15] H. Praptiwi. Inokulasi bakteri dan pemasangan cincin atau ligatur untuk induksi periodontitis pada tikus. Maj ked gi 2008; 15(1), pp. 81-89.

[16]. A. Chatterjee, K. Debnath, N.K.H. Rao. A comparative evaluation of the effi cacy of curcumin and chlorhexidine mouthrinses on clinical infl ammatory parameters of gingivitis: A double-blinded randomized controlled clinical study. Journal of Indian Society of Periodontology 2017;21(2), pp. 132137.

[17]. H.N. Farjana , S.C. Chandrasekaran, B. Gita. Effect of Oral Curcuma Gel in Gingivitis Management - A Pilot Study. Journal of Clinical and Diagnostic Research. 2014;8(12), pp. ZC08-ZC10 